\title{
Eksplorasi Etnomatsains pada Lumpia Semarang serta Implikasi dalam Pembelajaran Matematika dan Sains
}

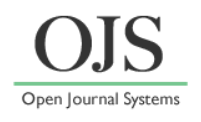

\author{
Subekti Anjarwati ${ }^{1 *}$, Anggi Erna Aryani ${ }^{1}$, Fika Fa'aliyatul Azizah ${ }^{2}$, \\ Ahmad Anis Abdullah ${ }^{1}$ \\ ${ }^{1}$ Program Studi Pendidikan Matematika, FKIP, Universitas Alma Ata \\ ${ }^{2}$ Program Studi Pendidikan Guru SD, FKIP, Universitas Alma Ata \\ *Email: subektianjarwati30@gmail.com
}

DOI: https://doi.org/10.33369/pendipa.6.1.183-192

\begin{abstract}
The learning process of mathematics and science until now still refers to the material in the book. Especially in the current era of the Covid-19 pandemic. They are more focused on material sent via social media that makes students tend to be bored and lazy. Based on these conditions, it is necessary to have a learning approach. One of them is a contextual learning approach, which is able to create an atmosphere of learning mathematics and science that is full of meaning in everyday life. In realizing contextual learning, it is necessary to have a balance of learning between existing school concepts and traditional culture. Local culture is a tangible form that can be found in everyday life and can be used for contextual learning. This study aims to explore the ethnomatscience concept contained in Lumpia Semarang which can be used as a medium for learning mathematics and science. This research is a descriptive study with an ethnographic approach, namely describing and analyzing cultural heritage. Based on the results of the literature review, several mathematical and sanic concepts found in the Lumpia Semarang meal section are displayed in the form of a tube. Research shows that the parts of the traditional food in Lumpia Semarang which are related to the concepts of mathematics and science, among others, have a shape like a tube with its constituent components in the form of vegetables, rice flour, egg white, and others with a variety of different shapes and sizes. has various elements of science.
\end{abstract}

Keywords: Ethnomatsciences, ethnomatematics, ethnoscience, spring rol.

\begin{abstract}
ABSTRAK
Proses pembelajaran matematika dan sains sampai saat ini masih mengacu pada materi dalam buku. Apalagi di era pandemi Covid-19 saat ini, mereka lebih fokus pada materi yang dikirim melalui media sosial hal ini membuat siswa cenderung bosan dan malas. Berdasarkan kondisi tersebut, maka diperlukan adanya pendekatan pembelajaran. Salah satunya yaitu pendekatan pembelajaran yang kontekstual, yang mampu menciptakan suasana pembelajaran matematika dan sains yang penuh makna dalam kehidupan sehari-hari. Dalam mewujudkan pembelajaran kontekstual perlu adanya keseimbangan pembelajaran antara konsep sekolah yang ada dengan budaya tradisional. Budaya lokal merupakan wujud nyata yang dapat ditemukan dalam kehidupan sehari-hari dan dapat digunakan untuk pembelajaran kontekstual. Penelitian ini memiliki tujuan mengeksplorasi konsep etnomatsains yang terkandung pada Lumpia Semarang yang dapat dijadikan sebagai media pembelajaran matematika dan sains. Penelitian ini merupakan penelitian deskriptif dengan pendekatan etnografi yaitu mendeskripsikan dan menganalisis tentang peninggalan kebudayaan. Berdasarkan hasil observasi dan studi pustaka diperoleh beberapa konsep matematika dan sanis yang terdapat pada bagian makan Lumpia Semarang yang ditampilkan dalam bentuk tabung. Penelitian ini menunjukkan bahwa bagian-bagian pada makanan tradisional pada Lumpia Semarang yang berkaitan dengan konsep matematika dan sains antara lain memiliki bentuk seperti tabung dengan komponen penyusunnya yaitu berupa sayuran, tepung beras, putih telur, dan lainnya dengan berbagai bentuk dan ukuran yang berbeda-beda yang memiliki berbagai unsur sains.
\end{abstract}

Kata kunci: Etnomatsains, etnomatematika, etnosains, lumpia. 


\section{PENDAHULUAN}

Proses pembelajaran matematika dan sains sampai saat ini masih mengacu pada materi dalam buku. Apalagi di era pandemi Covid-19 saat ini, mereka lebih fokus pada materi yang dikirim melalui media sosial hal ini membuat siswa cenderung bosan dan malas. Berdasarkan kondisi tersebut, maka diperlukan adanya pendekatan pembelajaran. Salah satunya yaitu pendekatan pembelajaran yang kontekstual (Shanti, Sholihah, \& Abdullah, 2018), sehingga mampu menciptakan suasana pembelajaran matematika dan sains yang penuh makna seperti dalam kehidupan sehari-hari (Herlina, 2020). Pembelajaran matematika dan sains dalam kehidupan sehari-hari yang benar-benar dapat mengungkap realitas budaya di sekitar siswa masih langka, dan materi yang diajarkanpun belum terintegrasi erat dengan budaya. Sehingga belum sesuai dengan ekspektasi kurikulum 2013, dalam mewujudkan pembelajaran kontekstual perlu adanya keseimbangan pembelajaran antara konsep sekolah yang ada dengan budaya tradisional.

Budaya lokal merupakan wujud nyata yang dapat ditemukan dalam kehidupan sehari-hari dan dapat digunakan untuk pembelajaran kontekstual. Beberapa penelitian yang terkait peninggalan budaya lokal yang sudah tereksplorasi baik berupa bangunan sejarah, kesenian, maupun adat istiadat tetapi masih sebatas konteks matematika saja(Rohayati, Karno, 2017) atau ilmu pengetahuan alam saja (Atmojo, 2018). Sementara itu pada kurikulum 2013 menuntut kita untuk belajar di sekolah agar lebih manusiawi, karena diharapkan siswa memiliki tiga kemampuan sekaligus yaitu kemampuan sikap, keterampilan, dan pengetahuan, yang akan lebih mendukung perkembangan setiap siswa. Oleh karena itu, perlu dilakukan suatu kegiatan pembelajaran yang inovatif yaitu menghubungkan bahan ajar dalam kehidupan sehari-hari siswa melalui sarana budaya yaitu belajar melalui pembelajaran etnomatsains(Hidayati, Rahmawati, Khomah, \& Abdullah, 2020).

Etnomatsains adalah salah satu cara pembelajaran matematika, fisika, kimia dan biologi yang dikaitkan dengan kebudayaan. Dengan demikian, dapat dikatakan proses pembelajaran kurikulum 2013 yang mengakibatkan siswa untuk bisa menganalisis, mengamati, dan mengkomunikasikan dapat terwujud(Richardo, 2017). Dengan adanya etnomatsains, maka siswa akan cenderung lebih aktif karena pembelajaran yang lama yang cenderung formal bisa diubah dengan dikaitkannya dalam kehidupan sehari-hari. Konsep inilah yang dapat membantu siswa tidak bosan dan tidak merasa malas dengan adanya pelajaran matematika(Abdullah, 2020).

Lumpia merupakan salah satu makanan khas Semarang yang digemari banyak kalangan. Sampai saat ini lumpia masih dipandang dari sudut kuliner saja, padahal keberadaan lumpia bisa dimanfaatkan untuk pembelajaran di sekolah dilihat dari bentuk dan materi penyusunnya. Penelitian ini memiliki tujuan mengeksplorasi konsep etnomatsains yang terkandung pada Lumpia Semarang. Adapun Urgensi dari penelitian ini adalah mengeksplorasi konsep matematika dan sains secara mendalam pada lumpia untuk meningkatkan motivasi siswa dalam belajar, membiasakan siswa berpikir kritis, dan meningkatkan kecintaan siswa pada produk budaya lokal di sekitaranya.

\section{METODE PENELITIAN}

Berdasarkan definisi etnomatematika, penelitian ini merupakan jenis penelitian kualitatif. Permasalahan dalam penelian ini adalah masalah yang berhubungan dengan unsur sosial. Oleh karena itu, metode yang digunakan oleh peneliti adalah metode deskriptif dengan pendekatan etnografi dan tipe studi kasus tentang makanan khas Semarang yaitu Lumpia, guna menggali lebih dalam konsepkonsep matematika dan sains yang terdapat di dalamnya. Teknik pengambilan data dalam penelitian ini adalah observasi, wawancara, studi pustaka, dan documentasi. Observasi, wawancara, dan documentasi dilakukan di produsen Lumpia di Kota Semarang, sedangkan studi pustaka yang diperoleh dari buku, jurnal, dan sumber literatur lain yang berhubungan dengan Lumpia. Setelah data diperoleh, selanjutnya dilakukan analisis data.(Rino Richardo, 2020).

Analisis data dalam penelitian ini meliputi analisis domain dan analisi taksonomi. Analisis domain dilakukan mendapatkan gambaran umum dan menyeluruh tentang Lumpia Semarang 
dilanjutkan dengan penentuan dan pengelompokan sesuai dengan kategori atau domainnya (Bakhrodin, Istiqomah \& Abdullah, 2019). Selanjutnya, data-data yang terkait dengan konsep-konsep matematika dikelompokkan dalam etnomatematika dan dijabarkan dalam domain matematika yang meliputi aljabar, geometri, kalkulus dan lainnya. Kemudian data yang terkaitan dengan konsep-konsep sains dikelompokkan etnosains dan dijabarkan dalam domain sains yang meliputi biologi, kimia, dan fisika. Selanjutnya analisis taksonomi dilakukan dengan cara menjabarkan domain-domain yang dipilih dalam penjelasan yang lebih rinci berdasarkan konsep-konsep matematika dan sains yang terdapat pada bagian Lumpia Semarang yang ditampilkan dalam bentuk tabel.

\section{HASIL DAN PEMBAHASAN}

Kuliner merupakan bagian dari budaya, kuliner sering kali diberi nilai simbolis sehingga dapat menjadi identitas suatu kelompok. Setiap Kuliner biasanya memiliki kekhasan dalam penyajiannya. Salah satunya makan khas daerah yang menjadi simbol atau icon adalah Lumpia Semarang. Lumpia Semarang merupakan hasil akulturasi budaya makanan Tionghoa dan Jawa. Dari segi ukuran, Lumpia Semarang tergolong unik, Lumpia Semarang berukuran lebih besar dibandingkan lumpia di daerah lain. Selain itu, Lumpia Semarang memiliki citra rasa yang khas jika dibandingkan dengan lumpia pada umumnya.

Lumpia Semarang mempunyai sejarah panjang yang sangat menarik untuk dijabarkan dari perspektif sejarah. Perkembangan Lumpia Semarang yang semakin meluas hingga diberbagai wilayah Semarang menyebabkan Lumpia Semarang tidak hanya menjadi kuliner khas Tionghoa, namun sudah menjadi ikon Kota Semarang (Sulistiyanto, 2020). Pemasaran Lumpia Semarang saat ini menjadi semakin mudah dengan dukungan berbagai media elektronik yang ingin memberitakan produk kuliner khas suatu daerah.

Lumpia yang biasa dikenal sebagai makanan khas Kota Semarang merupakan salah satu makanan bercita rasa etnis Tionghoa dan Jawa, dan telah menjadi ciri khas Tionghoa Peranakan di Semarang(Gumulya, 2017). Melalui lumpia etnis Tionghoa Semarang mampu menunjukkan eksistensinya ditengah masyarakat pribumi. Interaksi antara etnis Tionghoa dengan penduduk pribumi Semarang menjadi perantara berkembangnya kuliner lumpia. Lumpia memiliki cita rasa yang digemari banyak orang sehingga akulturasi budaya kuliner antara etnis Tionghoa dan penduduk pribumi semakin baik. Selain itu, keberadaan lumpian mampu mempererat hubungan etnis Tionghoa peranakan dengan penduduk pribumi, Lumpia juga mempererat hubungan antar sesama Etnis Tionghoa (Susanti \& Purwaningsih, 2015).

Jika diperhatikan lebih lanjut, pada makanan Lumpia ini memiliki bentuk seperti tabung dengan komponen penyusunnya yaitu berupa sayuran, tepung beras, putih telur, dan lainnya dengan berbagai bentuk dan ukuran yang berbeda-beda. Hal ini membuktikan bahwa makanan tradisional pada Lumpia Semarang dapat dijadikan media pembelajaran matematika maupun sains sekaligus pembelajaran untuk menghargai budaya-budaya lokal sebagai wujud nasionalisme terhadap bangsa. Menanamkan karakter kearifan budaya, dan jati diri bangsa pada generasi muda agar akar budaya bangsa yang telah berkembang tidak hilang. Dengan demikian diharapkan generasi penerusbangsa dapat bersikap dan berperilaku harmoni dan selaras, serta serasi antara manusia dengan alam, manusia dengan manusia, dan manusia dengan Tuhan. 
Tabel 1. Daftar Etnomatsains Pada bagian-bagian Lumpia Semarang

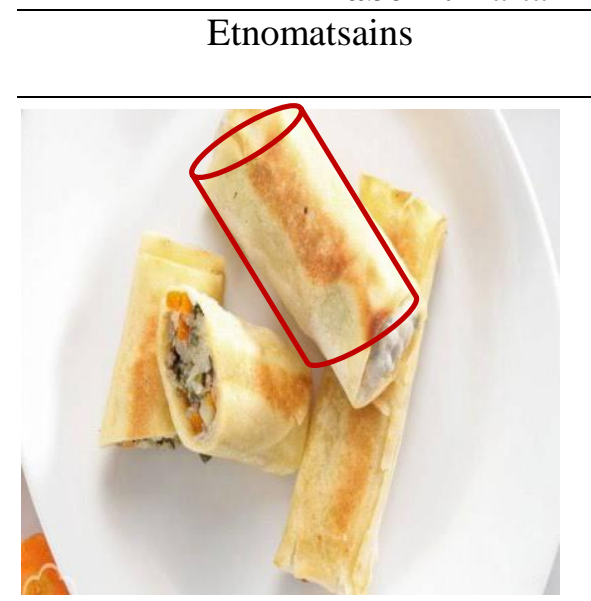
Domain

Implementasi

\section{Lumpia Semarang}

Matematika
(Konsep
Tabung)

\section{Lumpia Semarang yang memiliki bentuk} seperti gambar disamping yang bisa mengenalkan konsep tabung kepada siswa. Tabung merupakan bangun ruang tiga dimensi yang terbentuk atas dua buah lingkaran identik yang sejajar dan sebuah persegi panjang yang mengelilingi kedua lingkaran tersebut.

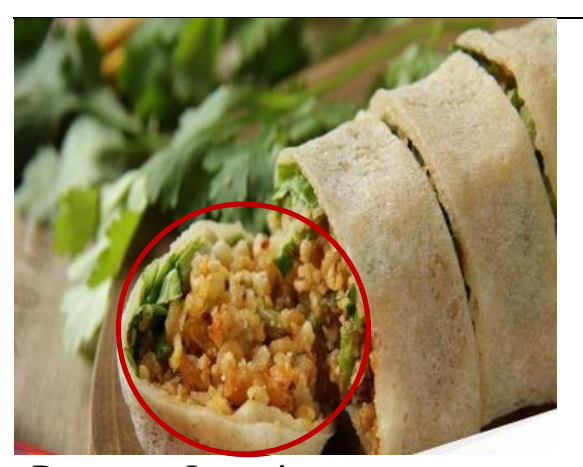

Potongan Lumpia

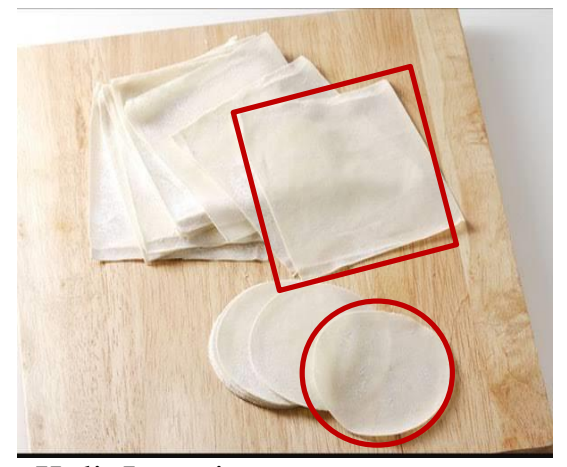

Kulit Lumpia

\section{Matematika \\ (Konsep \\ Lingkaran)}

Matematika

(Konsep

Lingkaran dan

Persegi)

\begin{abstract}
Penyajian Lumpia Semarang mempunyai bentuk seperti gambar disamping bisa mengenalkan konsep lingkaran kepada siswa. Lingkaran adalah bangun datar dimana setiap titik pada lingkaran mempunyai jarak yang sama terhadap suatu titik tertentu disebut pusat ingkaran. Jarak yang sama disebut jari-jari.
\end{abstract}

\section{Bahan utama dalam pembuatan Lumpia} Semarang adalah kulit lumpia. Seperti gambar disamping, kulit lumpia memiliki 2 bentuk yaitu lingkaran dan persegi. Dengan demikian, bentuk kulit lumpia bisa mengenalkan konsep lingkaran dan persegi kepada siswa. Lingkaran merupakan bangun datar dengan setiap titik pada lingkaran mempunyai jarak yang sama terhadap suatu titik tertentu yang disebut pusat lingkaran. Jarak titik pada lingkaran ke pusat lingkaran disebut jari-jari. Sedangkan persegi merupakan bangun datar yang memiliki empat sisi sama panjang dan keempat sudutnya sama besar, berbentuk sudut sikusiku. 


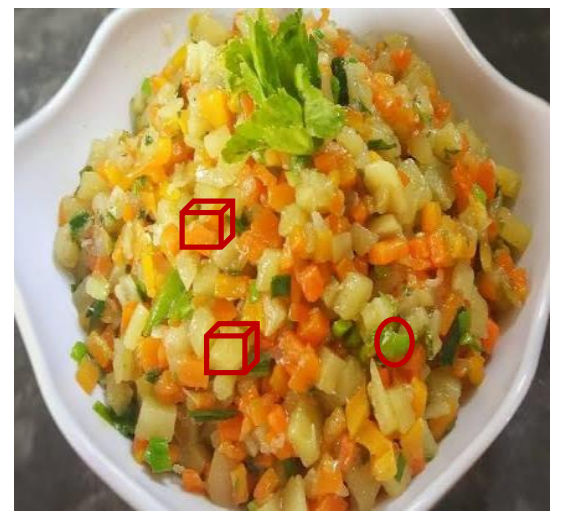

Isi Lumpia
Matematika

(Konsep

Lingkaran dan

Kubus)
Bahan isian yang digunakan dalam pembuatan Lumpia Semarang seperti gambar di atas menerapkan konsep lingkaran dan kubus. Terlihat bahwa potongan daun bawang sepeti lingkaran dan potongan kentang dan wortel dadu atau seperti kubus. Dengan demikian bentuk-bentuk tersebut dapat bisa mengenalkan konsep lingkaran dan kubus kepada siswa. Lingkaran adalah bangun datar dimana untuk setiap titik pada lingkaran itu mempunyai jarak yang sama terhadap suatu titik tertentu yang disebut pusat lingkaran. Jarak yang sama itu disebut jari-jari. Sedangkan kubus adalah bangun ruang tiga dimensi yang dibatasi enam bidang sisi yang kongruen berbentuk persegi. Kubus terdiri atas enam sisi, dua belas rusuk, dan delapan titik sudut.

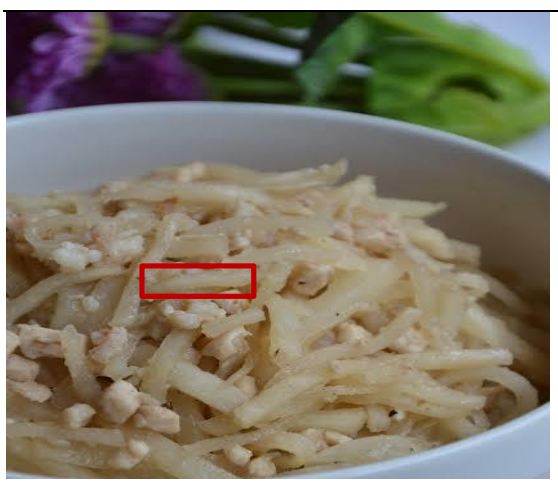

Matematika (Konsep Persegi Panjang)
Selain wortel, daun bawang dan kentang isian dalam Lumpia Semarang juga terdapat rebung (bambu muda). Terlihat bahwa potongan rebung seperti bentuk persegi panjang. Dengan demikian bentuk rebung tersebut dapat mengenalkan konsep persegi panjang kepada siswa. Persegi panjang adalah bentuk bangun datar dua dimensi yang yang terdiri dari dua pasang sisi yang masing-masing sama panjang dan sejajar dengan pasangannya, serta memiliki empat buah sudut yang semua sudutnya merupakan sudut siku-siku. 


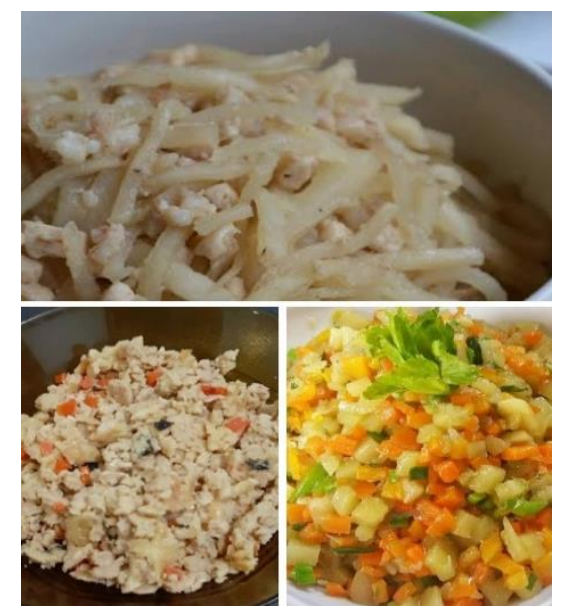

Isi Lumpia

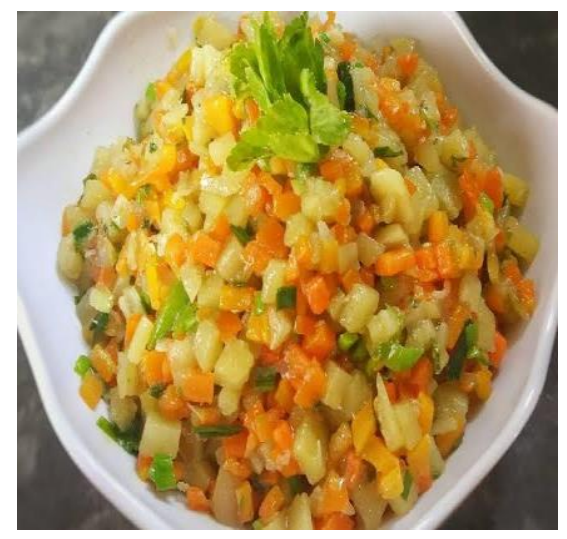

Biologi (Konsep

Zat Makanan dan Fungsinya bagi Manusia)
Isi dari Lumpia Semarang biasanya yang terdiri dari rebung, kentang, wortel, serta daging ayam. Oleh karena itu, pada gambar disamping isi lumpia biasa digunakan untuk mengenalkan konsep himpunan pada siswa. Himpunan adalah kumpulan benda-benda yang dapat didefinisikan dan diukur dengan jelas sehingga dapat diketahui apakah termasuk atau tidaknya dalam suatu himpunan tertentu.

Isi Lumpia

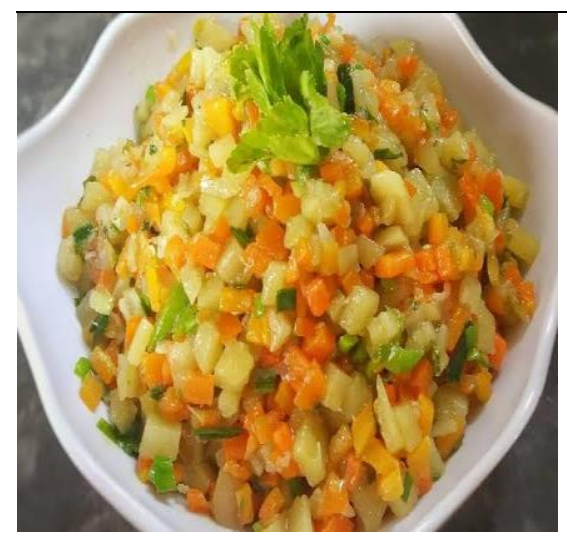

Isi Lumpia

\section{Biologi (Konsep Vitamin) \\ Wortel merupakan salah satu komponen dalam isian Lumpia Semarang yang dipotong seperti dadu dan memiliki banyak vitamin, yaitu Vitamin A, Biotin (Vitamin B), Vitamin K1 dan Vitamin B6. Daun bawang yang dipotong seperti lingkaran tersebut juga memiliki kandungan vitamin yaitu Vitamin A dan Vitamin K. Kentang yang dipotong dadu mirip dengan kubus memiliki kandungan vitamin yaitu Vitamin C.}

Dalam isian Lumpia Semarang salah satunya yaitu terdapat kentang. Kentang terdiri dari 66-90\% karbohidrat. Oleh karena itu, kentang menjadi salah satu sumber karbohidrat yang dibutuhkan oleh tubuh. Karbohidrat merupakan sumber energi utama bagi tubuh. Setiap molekul karbohidrat terdiri atas oksigen, karbon, dan hidrogen. Satu gram karbohidrat dapat menghasilkan sekitar 4,1 kilo kalori (kkal). 


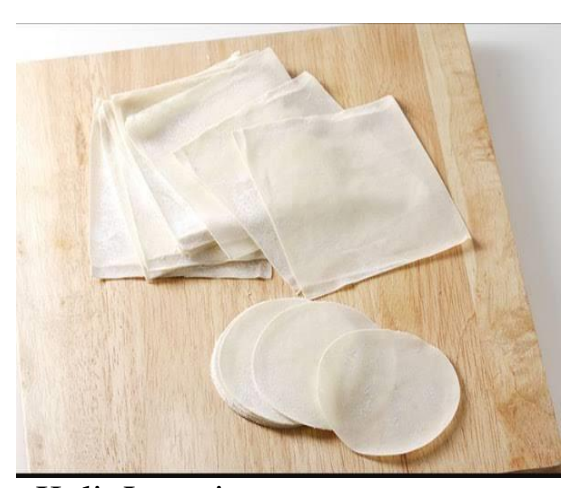

Kulit Lumpia

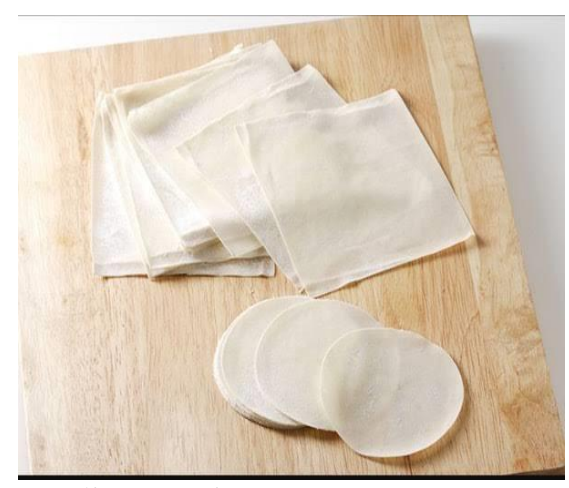

Kulit Lumpia

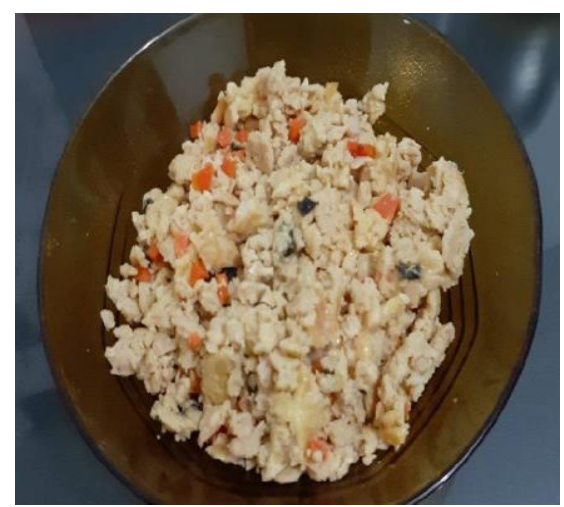

Isi Lumpia
Biologi (Konsep

Zat Makanan dan Fungsinya bagi

Manusia)

Biologi (Konsep Protein)

Biologi (Konsep Nutrisi)
Komponen pembuatan kulit lumpia salah satunya adalah tepung. Tepung mengandung karbohidrat yang dibutuhkan oleh tubuh. Karbohidrat merupakan suatu zat gizi yang berfungsi sebagai sumber energi utama bagi tubuh. Setiap molekul karbohidrat terdiri atas oksigen, karbon, dan hydrogen. Sedangkan setiap gram karbohidrat mampu menghasilkan 4,1 kilo kalori (kkal).
Selain tepung, putih telur juga merupakan komponen campuran dalam pembuatan kulit lumpia. Sekitar $90 \%$ dari total kandungan putih telur adalah air, dan $10 \%$ sisanya adalah protein. Putih telur juga mengandung kalium dan natrium. Selain itu, keunggulan lain dari protein adalah rendah kalori tetapi kaya protein. Dan $67 \%$ total protein pada telur beasal dari putih telur.

Daging ayam juga merupakan komponen isian Lumpia Semarang. Daging ayam merupakan makanan yang bergizi tinggi dan secra umum mengandung beraneka nutrisi diantaranya yaitu: Protein, Karbohidrat, Lemak (Lemak Jenuh, Lemak Tak Jenuh Ganda, dan Lemak Tak Jenuh Tunggal), Kolestrol, Vitamin A, Vitamin B (Vitamin B1, Vitamin B3, Vitamin B5, Vitamin B6, dan Vitamin B12), Vitamin D, Vitaimin E, serta Mineral (Zinc, Selenium, Kalium, Natrium, Fosfor, Tembaga, dan Zat Besi). 


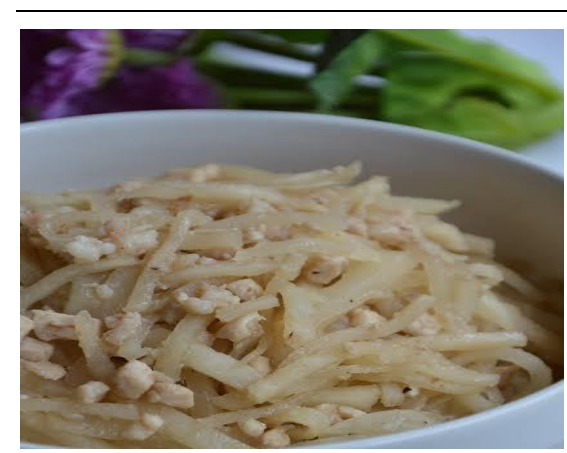

Isi Lumpia

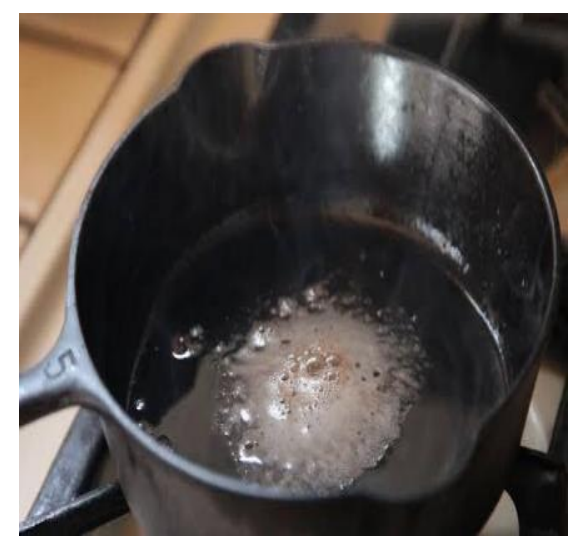

Titik Didih Minyak
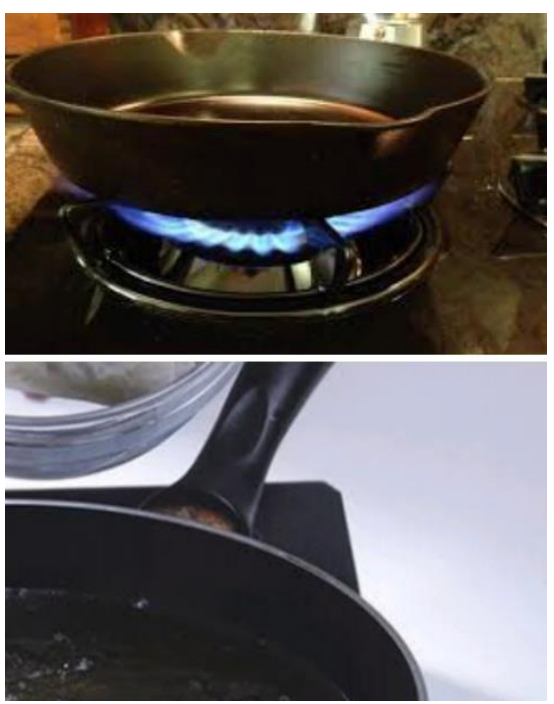

Konduksi, Konveksi, dan Isolataor
Biologi (Konsep Salah satu isian dalam Lumpia Semarang Vitamin) adalah rebung. Rebung dalam Lumpia Semarang dipotong secara memanjang. Rebung juga mengandung Vitamin A, vitamin B kompleks dan Vitamin E.

Fisika (Konsep Suhu)

Fisika (Konsep Perambatan Kalor)
Titik didih minyak ditandai dengan munculnya asap dari lemak atau minyak yang sedang dipanasakan. Titik didih minyak goreng rata-rata memiliki suhu $175^{\circ} \mathrm{C}$.

Dengan pemanasan berulang minyak goreng, suhu titik asap akan menurun dan pemanasan rata-rata menurun $11^{\circ} \mathrm{C}$ setiap kali pemanasan, yang berarti kandungan asam lemak bebas meningkat dengan pemanasan.

Perambatan kalor atau disebut juga dengan perpindahan panas adalah perpindahan energi akibat perbedaan suhu antara dua tempat yang berbeda. Perpindahan panas meliputi proses masuk dan keluarnya panas. Pada gambar di samping terdapat tiga permabatan kalor yaitu: konduksi adalah perpindahan kalor suatu zat padat yang tidak diikuti perpindahan partikelnya (api ke wajan), konvensi adalah perpindahan kalor melalui suatu zat perantara dan disertai perpindahan partikelnya (wajan ke minyak,dan isolataor adalah bahan yang tidak dapat menghantarkan panas dengan baik (kayu pada pengorengan). 


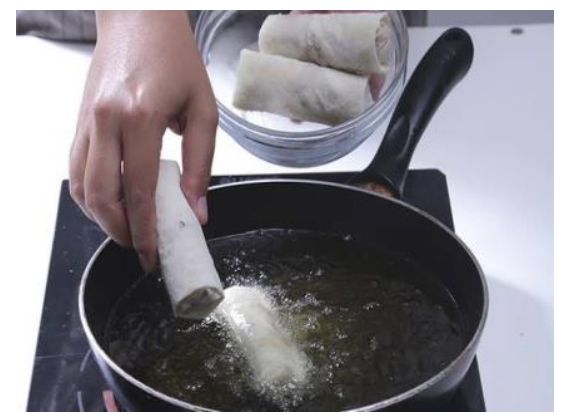

Lumpia saat di Goreng
Fisika (Konsep Lumpia saat di Goreng akan mengapung di Hukun Archimedes) atas minyak. Hal ini sesuai dengan Hukum Archimedes yang menjelaskan bahwa hubungan antara gaya berat dan gaya ke atas ketika suatu benda ditempatkan di air. 
Tabel 1 di atas menunjukkan bahwa konten etnomatsains yang ada pada makanan Lumpia Semarang sangat banyak sekali, sehingga bisa digunakan dan dikembangkan untuk media pembelajaran matematika maupun ilmu pengetahuan alam berbasis budaya di sekolah baik berupa buku ajar maupun media pembelajaran lainnya. Dengan demikian pembelajaran matematika maupun ilmu pengetahuan alam menjadi lebih bermakna, menyenangkan, dan mampu meningkatkan motivasi siswa dalam belajar matematika dan ilmu pengetahuan alam serta dapat menanamkan nilai-nilai kearifan lokal kepada siswa(Shanti et al., 2018). Siswa menjadi lebih bangga dan mampu memaknai nilai-nilai budaya bangsa dengan ilmu pengetahuan yang dimilikinya.

\section{KESIMPULAN}

Berdasarkan pembahasan diatas dapat disimpulkan bahwa bentuk Lumpia Semarang dan bahan penyusunnya memuat konsep matematika yang meliputi konsep bangun datar (persegi, bujur sangkar, lingkaran), konsep bangun ruang (kubus dan tabung), serta konsep himpunan. Sedangkan dalam konsep sains yaitu biologi ditemukan pada kandungan zat makanan penyusun Lumpia Semarang, sedangkan konsep fisika (konsep suhu, perambatan kalor, dan hukum Archimedes) ditemukan pada proses pembuatan Lumpia Semarang. Hasil penelitian ini bisa digunakan untuk pengembangan media pembelajaran matematika dan sains di sekolah.

\section{UCAPAN TERIMA KASIH}

Terimakasih disampaikan kepada Kemendikbud dan Universitas Alma Ata yang telah mendanai dan membimbing penelitian ini melalui Program Kreativitas Mahasiswa (PKM).

\section{DAFTAR PUSTAKA}

Abdullah, A. A. (2020). Etnomatematika; Eksplorasi Transformasi Geometri Pada Ragam Hias Cagar Budaya Khas Yogyakarta. Jurnal Ilmiah Soulmath : Jurnal Edukasi Pendidikan Matematika, 8(2), 131.

Atmojo, S. E. (2018). Pengembangan Perangkat Pembelajaran Ipa Terpadu Berpendekatan Etnosains. Jurnal Pendidikan Sains (Jps), $6(1), 5$.
Bakhrodin, Istiqomah, U., \& Abdullah, A. A. (2019). Identifikasi Etnomatematika Pada Masjid Mataram Kotagede Yogyakarta. Soulmath;Jurnal Ilmiah Edukasi Matematika, 7(2), 113-124.

Gumulya, D. (2017). Pencampuran Budaya Cina, Jawa, dan Belanda pada Budaya Makan Cina Peranakan. ANDHARUPA: Jurnal Desain Komunikasi Visual \& Multimedia, 3(02), 130-143.

Herlina. (2020). Upaya Meningkatkan Aktivitas dan Hasil Belajar Kimia dengan Pendekatan Contextual Teaching Learning di Kelas X SMAN 7 Rejang Lebong. PENDIPA Journal of Science Education, 4(1), 24-30.

Hidayati, N., Rahmawati, A. Y., Khomah, I., \& Abdullah, A. A. (2020). Identifikasi

Etnomatsains $p$ ada Tradisi Gunungan di Kraton Yogyakarta. 4(3), 52-59.

Richardo, R. (2017). Peran Ethnomatematika Dalam Penerapan Pembelajaran Matematika Pada Kurikulum 2013. LITERASI (Jurnal Ilmu Pendidikan), 7(2), 118.

Rino Richardo. (2020). Pembelajaran Matematika Melalui Konteks Islam Nusantara: Sebuah Kajian Etnomatematika di Indonesia. Jurnal Pendidikan Matematika, 3(1), 86-98.

Rohayati, Karno, \& C. (2017). Identifikasi Etnomatematika pada Masjid Agung di Yogyakarta. Prosiding. Seminar Nasional Pendidikan Matematika, 3, 1-8.

Shanti, W. N., Sholihah, D. A., \& Abdullah, A. A. (2018). Meningkatkan kemampuan berpikir kritis melalui ctl. Jurnal Pembelajaran Matematika, 5(1), 98-110.

Sulistiyanto, R. (2020). Wisata Sejarah Murah Meriah di Semarang Oleh: Jurnal Gema Wisata, 16(1), 629-646.

Susanti, I. E., \& Purwaningsih, S. M. (2015). Lumpia Semarang Pada Masa Orde Baru (Lumpia sebagai Identitas Budaya Etnis Tionghoa Peranakan Semarang). Avatara EJournal Pendidikan Sejarah, 3(3), 384-390. 